\title{
The constructivist museum and the web
}

\author{
Yvonne Hellin-Hobbs \\ Pheasant Cottage \\ 35, Briantspuddle \\ Dorchester \\ Dorset DT2 7HT \\ hobbs66@btinternet.com
}

\begin{abstract}
As long as there have been museum collections they have been interpreted and displayed according to the prevailing philosophy of their time. In the post-modern period many schools of thought have influenced museum interpretation, amongst them Constructivism. The model of the Constructivist Museum is one where visitors are involved in the process of interpretation and the construction of knowledge. Though examples of this have been rare in the world of physical museum display, with advances in technology and the development of the World Wide Web, visitors to online museums have more opportunity for participation.
\end{abstract}

This paper examines how and if the concept of the Constructivist Museum is manifesting itself in the world of museums and the Web. Using several online projects as examples, it seeks to discover how user-generated content is being incorporated into museums and why there is a reticence amongst the public to dispute or edit official interpretation. It examines issues of trust, authority and the challenges to the traditional hierarchy of knowledge that arise in its doing so.

This paper contends that whilst user-generated content is often encouraged on museum websites it is rarely allowed to infiltrate the official museum interpretative process and suggests that reluctance amongst museum professionals and curators to relinquish power and control might be responsible. It also suggests that museums might need to review the way they interact with their users in terms of presenting content on existing internet platforms.

Constructivism. Tagging. Folksonomy. Museums. Philosophy. Web 2.0. User-generated content.

\section{INTRODUCTION}

Museums, as repositories of knowledge and 'the past', have always been directly linked to the current philosophical outlook of their time. From the very first enterprises that we recognise as museums, the epistemological framework in place at that point in time was relevant to the hierarchy of knowledge and how it was disseminated. During the Renaissance the studioli of princes represented an ownership of knowledge and demonstration of power; culture was a currency displayed and interpreted according to allegory and symbol. During the Enlightenment museums came to represent the order and rationality associated with a scientific taxonomy and a linear depiction of time culminating in modern man and his achievements. Science was held responsible for the influence of reason.

From the early $19^{\text {th }}$ century museums began to emerge as instruments of public education and control. Visitor numbers were restricted and the public were supervised in the belief that restricted public display would reinforce the power of the museum or collection owners. Instruction, through the presentation and interpretation of artefacts, was in the hands of the curators, and curatorial interpretation remained part of the system of control. Through Romanticism, Positivism and Modernism the prevailing philosophy has continued to influence our view of the world and the way our past is presented to us, both through objects and the language used to interpret them.

In the post-modern period various theories of knowledge and of learning have emerged that have a relevance to museums and the way they operate, including the Constructivist model posited by George Hein (1998). This model challenges the traditional hierarchic model of dissemination of knowledge still adhered to rigidly by many museums; a 'top-down' model, whereby artefacts are interpreted by professionals and that interpretation is presented to the audience. Hein suggests that knowledge and meaning is constructed in the mind of the learner, or museum visitor, based on their prior knowledge and beliefs. 
This would suggest a 'bottom up' model of interpretation which allows the visitor to draw their own conclusions about the meanings of exhibits.

During recent decades burgeoning new information technology has meant that more and more museums now have a presence on the World Wide Web. The emerging, and fast expanding, world of interactive media has revealed new opportunities for museums to allow their users to interact, not only with their collections, but with their repositories of knowledge. This is already allowing different systems of interpretation to emerge, and new ways of assessing collections to be explored. Non museum professionals are now being invited to create their own input into museum collections and exhibitions. This is known as user-generated content (UGC).

\section{CHANGING PERSPECTIVES OF MUSEUM VISITING}

So far in their existence, museums have concentrated almost exclusively on presenting an impersonal history seen through the detached view of the academically-trained historian (Merriman, 1991, p. 130)

Merriman sees the way museums disseminate 'knowledge' in a 'top down' framework could constitute an apparatus to ensure maintenance of the dominant social system and recognises the cultural empowerment implicit in visitors taking control of interpretation and exhibition. But the advent of the World Wide Web and in particular the technology known as Web 2.0 has altered the balance of power in the realm of museum visiting.

One of the leaders in the field of museum web presence is London's Victoria and Albert Museum. Gail Durbin was a museum educator who made a study of different learning styles for the interpretative plan for the V\&A's British Galleries, and included 'interactive' devices with varying levels of user participation. By 2003 she was Head of Online and already saw the danger of museum websites replicating traditional museums in terms of the 'one way dissemination of information'.

She maintains that galleries and museums fail when they take no account of how people learn from museum objects and she believes that it's important that visitors become actively involved with the content of the museum.

Many traditional displays are planned round what museums know and want to tell others. They might be defended as educational but they do not come out of understanding of educational theory and how people learn (Durbin, 2003, p. 2).
In her view 'interactivity' means 'any use of new media where the user can influence the outcome. 'Participation in a web context is a particular kind of interactivity which encourages a sense of involvement' (Durbin, 2003, p. 3).

Participation is the key and Web 2.0 provides platforms from which people can interact with each other and with data in real time through phones, cameras and other devices as well as sitting at a computer. The Web is now a network of all connected devices;

The Web is no longer a collection of static pages of HTML that describes something in the world. Increasingly, the Web is the world- everything and everyone in the world casts an "information shadow” (O’Reilly \& Battelle, 2009, p. 2).

With the advent of Web 2.0 so came social media sites like Facebook, Twitter, My Space, You Tube, Flickr and a myriad others, over which people communicate with each other, and museums have the potential to communicate and interact with their public.

\subsection{Tagging, folksonomies and UGC}

Three products of museum visitors having been encouraged to participate in the museum experience on the World Wide Web are:

- Tagging; the process of users adding their own keywords to the descriptions of museum objects.

- Folksonomies; the alternative taxonomy of those objects thereby created by public use of tagging and describing objects according to their own interpretation.

- UGC, the user-generated content that is uploaded by users of the museum websites. This can include photographs, comments, personal memories.

The following three case studies are of museum related websites that incorporate UGC asking whether they fulfil the remit of Constructivist Museum and whether their content feeds back into the museum experience in any significant way.

\subsection{Steve.museum}

In 2005 The Metropolitan Museum of Art in New York ran an experiment which entailed a group of volunteers supplying keywords, or 'tags', for thirty images in the museum's collections. The terms supplied were compared to curatorial cataloguing from the museum's collections management system and the new 'unique' keywords were validated for relevance by a group of staff members. 'For the 30 images tested, approximately $80 \%$ of terms submitted by the community 
cataloguers were unique- new additions to the museum's documentation' (Wyman et al., 2006, p.2).

We are interested in discovering whether and how non-professionals' descriptions of artworks differ from professional cataloguing, as well as how volunteer taggers may experience the activity of looking at and describing museum collections (Trant et al., 2007, p. 1).

This pre-test was the beginning of a major tagging experiment which began in 2006, known as Steve.museum (http://www.steve.museum), in which nine major art museums in America joined forces in allowing crowd cataloguing of their collections.

Working together on steve.museum provided a safe 'third space', not identified with any of the partners, where experimental approaches could be explored without a direct impact on existing institutional services. It also enabled crosscollection perspectives to develop broadening the relevance of the work (Trant, 2009, p. 7).Steve.museum assembled a test set of 1,784 works of art, with contributions from all participating museums and a number of other interested museums. Works were solicited that represented a broad range of styles and periods, and represented the full range of types of works in art museum collections (Trant,, 2009, p. 13).

The tools used for tagging were already in place in social bookmarking sites like Flickr.com and del.icio.us.com. whilst commercial sites like Amazon.com were increasingly employing usersupplied keyword indexing to improve access.

What distinguishes tagging as a form of visitor engagement from other kinds of "interactive" museum programs is that the impetus lies not with the institution but with the individual: the visitor initiates and completes the experience (Trant \& Wyman, 2006, p.3).

Steve has been through various different permutations of information displayed in order to ascertain whether the presence of museum documentation influences tagging, if user behaviour changes when other tags are visible, if tags and metadata might encourage useful additions to the description and whether users became more engaged when asked to tag groups of similar works.

In January 2009 a report was published on the results of research conducted by Steve.museum between October 2006 and December 2008 (Trant, 2009). The paper concluded that a folksonomy of 36,981 terms was gathered, comprising 11,944 terms in 31,031 term/work pairs.
The results were analysed and showed that the vast proportion of public tags did not appear in the official museum catalogue descriptions.

\begin{abstract}
... when the full steve.museum tag set was compared to the assembled Museum Documentation, $86 \%$ (35,307 tags) were not found in Museum Documentation as either a full or a partial match. [This] represents a significant difference between the vocabulary of tagging and the vocabulary of museum documentation (Trant 2009, p.37).Many taggers are supplying new terms, relating primarily to what they can see in the image. Museums do not have these kinds of terms in their on-line records (Trant, 2009, p. 41).
\end{abstract}

The published results do not indicate that the tags were in any way incorporated into the participating museums' official interpretation but since the Steve experiment began online tagging is much more common and popular in the world of the online museum. But the point of the Steve project was to enable vernacular language to be used to describe art objects normally interpreted using the specialist language of the art historian, thereby allowing a degree of audience interpretation of the objects.

Jennifer Trant asserts that the significant number of terms tagged by more than one visitor 'revealed that users see, and presumably recall, some details of images that are not explicitly documented by professionals, thus suggesting some scope for using these terms to aid in discovery' (Trant et al. 2007, p.9).

Tagging objects in museums' collections takes their engagement with users further than the early use of the Web by museums, to publish 'curated' online exhibition and educational materials.
All museums have a common goal: to encourage user engagement with collections' (Wyman et al. 2006, p.8). 'Tagging lets us temper our authored voice and create an additional means of access to art in the public's voice' (Wyman et al., 2006, p .2).

However, online museum collections still mirror physical museums in that one still has to visit each museum site separately to search the collections, and the information provided is structured around the goals of the museum, which may not correspond with those of the user (Trant, 2009, p.2).

\section{3. Creative Spaces}

The V\&A led Creative Spaces project, http://vna.nmolp.org/creativespaces/, is one facet of the National Museums Online Learning Project, NMOLP, which brings together nine national museums in England; the Victoria and Albert 
Museum as lead partner and the Natural History Museum, the British Museum, Sir John Soane's Museum, Tate, the Wallace Collection, the Imperial War Museum, the Royal Armouries and the National Portrait Gallery. The school educational element is entitled 'WebQuests' and is centred on National Curriculum Key Stage material.

Creative Spaces, originally 'Creative Journeys', was 'conceived as a location for user-generated content around the individual user's inspirational connections with museum collections' (Bayne et al., 2009 , p. 18). Aimed at adult learners, it also combines an element of social participation. The Creative Spaces facet asks users the question, 'What inspired you today?' Through Creative Spaces people can browse the collections of all nine museums, use keywords to locate objects that inspire them, collect those objects and comment upon them in their own notebooks and join with other user groups with similar interests. They can also import content from other areas of the web or personally created content (Bayne et al., 2009, p. 33). This would seem an ideal example of the constructivist principle of visitors making their own meaning

The project was launched in February 2009, to little acclaim and scant publicity. A Google search for it at time of writing uncovered some blog posts from March 2009 questioning the potential value of the site and an entry portal via the V\&A website but no description or explanation of what Creative Spaces is, what it is for or how one could use it.

At June 2009, there were 582 Creative Spaces user accounts, 240 notebooks and 74 groups. A proportion of the early content has been created by partners, but many newer accounts appear to belong to users without professional connections to the museums (Bayne et al., 2009, p. 18).

In March 2010 | counted 336 notebooks, 818 people and 45 groups that show up on the site; not a huge increase in a year and no noticeable changes in the way the site operates.

The NMOLP final report does acknowledge that there are limitations in the way the site operates. Searches are limited to favourites, searching and notebook creation, are two distinctly different areas of activity that cannot happen simultaneously and there are boundaries between 'different objects, types of content and types of activity' (Bayne et al. 2009 , p. 23). The messiness and spontaneity of a paper version of the notebook application is lost in the ordered structure of the online version.

There are also concerns about sharing. User's notebooks can be shared through various social networking sites but objects cannot be shared independently of the notebooks. 'The implication here is that the user's content is for sharing, but not the museum's content, and not outside of the boundaries of the site itself' (Bayne et al. 2009, p.23). Also not all of the digitized collections of the participating museums are available through Creative Spaces. Some objects are only available through the partner museums' search engines (Bayne et al., 2009, p. 29).

Whilst the project is to be applauded for the bringing together of nine independent institutions and overcoming major copyright issues, the main criticism seems to be that the information, expertise or simply experiences that are noted and shared in the confines of Creative Spaces remain there and do not feed back into the physical museums or their documentation. They are not even available as part of the participating museums' general websites.

\begin{abstract}
... user-generated content and tags from the Creative Spaces site do not feed back into the museums' databases or curatorial web spaces. Nor, as we will see, is Creative Spaces content intended, at present, to be published by the partners on other parts of their sites (Bayne et al. 2009, p. 21).
\end{abstract}

The museum-generated content that is imported into notebooks etc. comes with its museumgenerated description and title, 'These can be edited later, but the message is clear - the object comes coupled with its own expert interpretation' (Bayne et al., 2009, pp. 21-22). The report found that most partners in the project did not expect the content of the site to 'inform or permeate other museum spaces' (Bayne et al., 2009, p. 22).

The site still sits outside of the museum proper and represents a possible Constructivist Museum experience that does not feed back into the institution.

In contrast, the Brooklyn Museum site http://www.brooklynmuseum.org/opencollection/coll ections/ encourages not only tagging but sharing and helping others to find objects, playing games with tags and, with the expansion of their online collection, an opportunity for users to add to the museum record for objects.

\section{4 Science Museum Object Wiki}

At the Science Museum in London another experiment began in 2008 with the creation of the Object Wiki,

http://objectwiki.sciencemuseum.org.uk/. A wiki is a site that allows users to upload and edit information, changing the content of the site as they do.

It was linked to an exhibition titled 'Dan Dare and the Birth of Hi-Tech Britain' running from April 2008 
- October 2009, as there was room within that project for trials and 'because many of the objects had nostalgic appeal' (Looseley \& Roberto 2009, p. 2). It currently represents 561 objects on the site, mostly from the twentieth century, divided into eight different categories and users are requested either to a) edit or b) add information to the museum documentation on them relating to how they were made, or how they worked or just add their personal memories and experiences.

'The wiki was launched at the same time as the exhibition, and terminals within the gallery space made it possible for people to use it while they visited the exhibition' (Looseley \& Roberto 2009, p. 2 ), as well as being available offsite. This would seem to represent an ideal example of visitor meaning-making within the museum by using an online application.

The Science Museum gives visitors the option to create an account and login before editing, but they are not obliged to do so. Visitors can also enter their e-mail address which enables users to leave messages for the attention of other users and 'talk' to each other. At time of writing the site's homepage had received 715,053 visits. http://objectwiki.sciencemuseum.org.uk/ (19 March 2010).

It soon became apparent that 'the vast majority of contributions to the wiki from members of the public would originate via Google searches' (Looseley \& Roberto, 2009, p.3). This would suggest an already knowledgeable audience searching for objects that they are familiar with, and commenting on the most popularly used or owned objects featured on the wiki.

The museum hoped to get niche expertise audiences who would correct any inaccurate information in the museum record but by and large it attracts nostalgic information rather than fact based historical information. In a paper given at the Museums and the Web Conference in 2009, Frankie Roberto and Rhiannon Loosely note that the public appear to have been reticent to edit existing information whilst preferring to share memories and suggest this reticence might be caused by the perceived authority of the museum itself (Looseley \& Roberto, 2009, p. 1).

Roberto suggests the reason the public might feel more comfortable contributing to Wikipedia is because the site feels more democratic and makes people feel their contribution is more valid, whereas a wiki linked to a museum website gives the user the feeling that they are somehow challenging the expertise and authority of the museum itself.

\section{TRUST, AUTHORITY AND THE HIERARCHY OF KNOWLEDGE.}

This paper set out to discover whether electronically delivered user-generated content was allowing museums to fulfil George Hein's vision of the Constructivist Museum on the Web. As the results of the case studies have shown, visitors to museums and their associated online presence certainly can have different interpretations of material and express those interpretations in ways, and words that sometimes challenge the 'truth' of official museum interpretation. Constructivism itself challenges the concept of absolute truth; it ascribes validity to personal meaning making and goes further;

If the mind constructs knowledge based on its previous experience-personal, social and contextual-then what criteria can be used to distinguish between correct and incorrect knowledge? (Hein, 2004, p. 360)

As visitors progress from being passive consumers to being active participants in museums, their content and the creation of knowledge associated with them there is an apparent undercurrent of unease amongst museum professionals as to how users will identify seemingly correct or incorrect knowledge and a reluctance to allow information not formally produced by the museum itself to be displayed as part of the museum's documentation or interpretation.

If the Constructivist Museum exists in terms of the World Wide Web and how the public use it in relation to museums then it seems to be an experience that is kept in a safe 'third place' outside of the museum proper whose creative content is not integrated into either the documentation or the exhibition content of the physical museum; that being so, it could be inferred that issues of trust, authority and the hierarchy of knowledge are involved in the reasons why.

There is no doubt that the public desire a degree of trust in the institution of the museum to represent the voice of authenticity and factuality; this complies with the historical background of the museum as educator. This trustworthiness though could be a barrier to presenting more contentious information, more of a hindrance than a help.

Within these experiments and in other cases of UGC on the Web, there is also the issue of the institution trusting the public. This brings up an issue known as 'radical trust' the trust that museums seems reluctant to put in the public not to abuse the system. Sending abusive material to a museum is not a new phenomenon, museums have always had contentious letters and feedback, 
but the fact that it is online is perceived as more anarchic, less able to be controlled.

In the Steve.museum experiment, there was a blacklist of unacceptable terms, but only 20 were ever tagged out of over 30,000 tags ascribed. The fact that taggers could not see what other people had tagged reduced the incentive to misbehave.

In Creative Spaces everything is kept in its own space, it doesn't feed back into the museum interpretation or website so the issue of trust is negated.

On the Object Wiki, the only abuse of the wiki occurred on the in gallery terminals where it was observed that groups of children were sending each other messages using the wiki site. When the system changed so that they were obliged to log in and supply an email address it presented enough of a barrier to stop the abuse.

It would seem that when people have to identify themselves, on a post it note wall or online, they are less likely to abuse the trust the museum might put in them. So attributing authorship, knowing the provenance, is key to letting the public make up their own minds about the authenticity of information, and trusting the public to moderate themselves.

Museums might also be nervous about the challenge to their authority. Neither Steve nor Creative Spaces represented a challenge to that authority as they are kept separate from their respective museum sites. On the Object Wiki, the public mostly contribute nostalgia, and no-one can say people's memories are wrong. On the other hand they are, it would seem, reticent to edit the museum documentation and so challenge the authority of the museum.

This has implications concerning the hierarchy of knowledge, as disseminated throughout the history of museums in that old 'top down' system. UGC represents a channel through which the specialist language of the curator can be challenged as visitors bring with them their own experience, their own generalised concepts and the language through which they can express their own meaning making. A reluctance to dilute the language of the expert and the erosion of a single voice of authority as more museum professionals take up the social media mantle as bloggers and tweeters, represent a 'letting go' of authority that some museum professionals are reluctant to embrace.

Another factor that has come to the fore in this research is that very little of what is happening on the Web in terms of UGC on museum websites seems to be actually feeding back into the museums proper. This could well be for the reasons mentioned above, authenticity, correct or incorrect knowledge or simply a reluctance to 'let go' of authority. It could also be because it is much easier to be seen to use the technology available to create separate experiences that satisfy the users' need to participate and contribute and can be justifiably left outside of the physical museum, or in some cases even outside of the museum's official website. It would seem, though, that such projects do fulfil some of the criteria of a Constructivist Museum far more than the museums that host them might, if only in that visitors can feel included in the process of meaning making instead of being passive receptors. What happens on these sites, whether through public tagging or uploading of their own content may not make a difference to the museums' point of view, but it does to that of the visitors who use them.

\section{CONCLUSION}

This paper concludes that in terms of Constructivism, electronically delivered UGC has the potential to go further towards fulfilling Hein's concept of the Constructivist Museum than many physical museum experiences can, or are allowed to do.

If we accept the concept that people construct their own interpretation of the museum experience, based on their values and prior knowledge museums should be prepared to allow that interpretation to be displayed and shared with other users, and even acknowledged by and incorporated into the museums' physical or online experience. At present the majority of UGC encouraged on museum websites is purely from individuals, but by allowing individuals to share their interpretation with others, group interpretation through shared cultural values and background could emerge. To an extent this is what Creative Spaces is trying to achieve, but it is too narrow and elitist to result in a wide ranging group interpretation process, and it is, as has been noted, very insular.

Finally, many museums are happy to encourage visitors to their own web spaces but less enthusiastic about taking their content onto the existing social media spaces that the public already use. More and more users expect content to be at their fingertips, when and where they want it, in other words, built upon existing platforms. In order to accommodate that situation it is possible that museums will have to rethink the way they are structured and bring themselves more in line with the structure of the web itself. 


\section{REFERENCES}

Bayne, S., Ross, J. and Williamson, Z. (2009) National Museums Online Learning Project final report, University of Edinburgh. http://www.malts.ed.ac.uk/staff/sian/nmolp/finalrepo it.pdf (29 July 2009)

Durbin, G. (2003) Using the Web for Participation and Interactivity.

http://www.archimuse.com/mw2003/papers/durbin/ durbin.html (24 February 2009)

Hein, G. (1998) Learning in the museum.

Routledge, London.

Hein, G. (2004) The Role of Museums in Society: Education and Social Action. Curator, 48 (4), pp. 357-363.

Looseley, R. and Roberto, F. (2009) Museums \& Wikis: Two Case Studies. In Trant, J. and Bearman, D. (eds), Museums and the Web 2009: Proceedings. Archives \& Museum Informatics, Toronto.

Merriman, N. (1991) Beyond the glass case: The past, the heritage and the public in Britain. Leicester University Press, Leicester.
O'Reilly, T. and Battelle, J. (2009) Web Squared: Web 2.0 Five Years On. http://www.web2summit.com/web2009/public/sche dule/detail/10194 (9 August 2009)

Trant, J. and Wyman, B. (2006) Investigating social tagging and folksonomy in art museums with steve.museum. Archives \& Museum Informatics, Toronto.

Trant, J., Bearman, D. and Chun, S. (2007) The eye of the beholder: steve.museum and social tagging of museum collections. In Trant, J. and Bearman, D. (eds), International Cultural Heritage Informatics Meeting (ICHIM07), October 24-26, 2007, Toronto, Ontario, Canada: Proceedings. Archives \& Museum Informatics, Toronto.

Trant, J. (2009) Tagging, folksonomy and art museums: results of steve.museum's research. Archives \& Museum Informatics, Toronto.

Wyman, B., Trant, J., Chun, S., Cherry, R. and Hiwiller, D. (2006) Steve.museum: An Ongoing Experiment in Social Tagging, Folksonomy, and Museums. In Trant, J. and Bearman, D. (eds.), Museums and the Web 2006: Proceedings. Archives \& Museum Informatics, Toronto. 